\title{
6
}

\section{DEFENDING THE BODY, DEFENDING THE SELF}

\author{
Women performers and the law in the 'long' \\ Edwardian period ${ }^{1}$
}

Viv Gardner

Royal Court Theatre, 9 April 1907:

A woman is arrested by a man, brought before a man judge, condemned by men, taken to prison by a man, and by a man she's hanged! Where in all this were her 'peers'? Why did men so long ago insist on trial by 'a jury of their peers'? So that justice shouldn't miscarry. A man's peers would best understand his circumstances ... (Edith Wynn Matthison as Vida Levering in Elizabeth Robins's Votes for Women, Act 2) ${ }^{2}$

Central Criminal Court (The Old Bailey), 4 June 1918:

Gentlemen ... First of all, you should ask yourselves: is this a libel on Miss Maud Allan? Now you have heard what the 'Cult of the Clitoris' means. Is it a libel upon Miss Maud Allan? I have told you it is a libel if it is written and published and if it tends to hold her up to dislike, in fact defames her character - and who can doubt that it did? But I cannot decide it, and therefore I will formally ask you, although all through this case everybody has assumed that there can be but one answer to that question ... (Lord Justice Darling, summing up in Crown v. Billing)

As if to prove Elizabeth Robins's point, and despite the judge's direction, it took the special jury at the Old Bailey only an hour and twenty-five minutes to find maverick independent MP Noel Pemberton Billing 'not guilty' of the charge of malicious publication of a false defamatory and criminal libel against the dancer and actress Maud Allan (Kettle, 1977: 63). The gentlemen of the jury vindicated the assertions implicit in a boxed paragraph published in Billing's journal, The Vigilante, on 16 February 1918, under the headline 'The Cult of the Clitoris'; this paragraph advised readers that Scotland Yard had only to seize the list of members about to attend a private performance of Oscar Wilde's Salome, in which Allan 
was to play the lead, to uncover several of the names of the estimated 47,000 'followers of Wilde' at large among the British cultural and political elite. By its verdict, the jury publicly declared Allan 'a sadist, a lewd, unchaste and immoral woman', whose performance would encourage 'obscene and unnatural practices among women' (Hoare, 1997: 177). This was, perhaps, as much a verdict on Allan's career and public image as on the legal case under scrutiny. Salome was her 'signature' role; she had first produced her Vision of Salomé in England, with its notorious 'Dance of the Seven Veils', ten years earlier in 1908.

In some ways, however, this infamous, complex and much-discussed case marks a watershed in the history of women performers' attempts to use the law to defend their reputations against public attack. The gender historian Lucy Bland sees this trial as 'pivotal' in 'the drawing up of battle lines in relation to the construction of a new, post-war womanhood, setting the stage for the [sensational] trials' of socially and sexually transgressive women that were to follow in the 1920s (Bland, 2013: 9). With the partial enfranchisement of women in February 1918, the qualification of women as parliamentary candidates in November 1918 and the swearing-in of the first female jurors in July 1920, the political, social and legal landscape for all British women changed significantly at the end of the war.

However, Allan was not just a woman but also a performer. She was defending her reputation on two fronts. For several decades before 1918 female performers had been one of the very public faces of professionalised women while still, for many, socially and sexually marginal. Allan's male co-plaintiff, the radical theatrical producer J. T. Grein, was given much less prominence in contemporary - and most subsequent commentaries on the case; the focus was on the dancer, and the names alleged to exist in Billing's notorious 'Black Book'. ${ }^{3}$ The 'Cult of the Clitoris' was just one of a series of legal cases brought by female performers between 1882 - and the second Married Women's Property Act in 1893, which gave married women the same powers to sue and be sued as men and spinsters and widows - and the end of First World War. From 1903 onwards, they did so in the shadow of the militant suffragists who were using their court appearances with increasing passion and skill to challenge both the law and society's unequal treatment of women. Women performers also used the courts to argue for self-determination and control, particularly of their public image. These were not the litigious widows of Renaissance drama (Stretton, 2005: 57-63), but public women seeking justice through the limited civil structures now available 
to them. Gone were the veils and victimhood that characterised nineteenth-century images of women in court (Nead, 2002), to be replaced by photographs, 'real' pictures, of women - some very well known - in fashionable dress.

\section{'A quagmire of meaningless and grotesque anomalies': the laws of defamation}

This chapter explores a number of legal cases brought by women performers and the issues that these raise. Most, but not all, of the cases were libel trials that also involved issues of copyright in images. A study of the Era for the period 1900-18 appears to show that female performers used the civil law, particularly civil and criminal libel, more frequently than their male counterparts. Their cases were also more frequently reported in the mainstream press. Actresses were good business, and media reporting of the trials - including the rhetoric and conduct of the representatives of the law - played a crucial role in the public perception of both plaintiff and defendant, and in reinforcing or challenging the public image of the 'actress'.

In 1903 an American lawyer, Van Vechten Veeder, described the English laws of defamation as 'absurd in theory, and often mischievous in practical operations' (Veeder, 1903: 546). As a measure of a civilised society's 'culture, liberality and practical ability ... to protect personal character and public institutions from destructive attacks, without sacrificing freedom of thought and the benefit of public discussion', he found Britain's laws of libel and slander wanting, a 'quagmire' of 'meaningless and grotesque anomalies' (Veeder, 1903: 546). The use, therefore, of Veeder's 'quagmire of grotesque anomalies' as a weapon for female litigants proved a double-edged sword. The defining criterion of defamation as 'an offence to personal character' was sufficiently ambiguous to allow many different types of prosecution, but the 'test' of defamation, that it should be an offence agreed by 'any reasonable person', was equally open to interpretation and bias - Justice Darling thought Billing's publication a libel; the jury of 'reasonable' men did not. In addition, Britain's case-law-based legal system means that the verdict in one case effectively creates law, by precedent, in any future case. ${ }^{4}$

The motives of the women in these cases might have been ambiguous - part personal, part professional and commercial - but the progress, conduct and outcomes of the libel cases were very much a 'measure of the culture, liberality, and practical ability' of the age, particularly as 
it related to women. The practical ability of the law to control women is demonstrated overtly in the Allan case. Allan stated that it was her 'ambition to be an actress as well as a dancer' (Bland, 2013: 33); in accepting the role of Salome in Wilde's play she was not repudiating her status as 'a modern classical dancer', but seeking to progress as she aged - she was 45 in 1918. Instead her professional life was all but destroyed by the outcome of the libel case, with its personal attack on her 'libidinous and obscene' performance (Hoare, 1997: 218-21).

Reputation and hierarchy were increasingly important in the theatre industry in the early twentieth century. The class status of women performers in particular had always been ambiguous, and the conflation of 'actress' and 'whore' remained an issue, particularly for dancers and chorus girls, or the more economically-vulnerable provincial and suburban players. The increased professionalisation and respectability of the stage as a career for men and women by the end of the nineteenth century paradoxically made 'reputation' an even more precious and precarious commodity for those who had it, and widened the gap between the reputable and disreputable in the profession. This was reinforced by an increased divide between the 'serious' and the popular stages. Women performers were almost always lumped together as 'actresses' whatever their professional expertise and area of employment (singer, dancer, comedienne, Shakespearean etc.), and 'serious' actresses increasingly sought to distance themselves from their singing and dancing lowercaste sisters (or former selves). These distinctions were in a state of flux, but important both personally and professionally, as many of these cases show. ${ }^{5}$

\section{'What constitutes an actress?': Thomas v. Frohman and A. and S. Gatti (1905-06)}

In 1905 Ethel Lucy Carrie Thomas, performing under the name of Ethel Karri, sued Charles Frohman and the Gatti brothers for damages for wrongful dismissal. Thomas had been engaged by actor-manager Seymour Hicks to play a Gibson Girl in The Catch of the Season at the Vaudeville Theatre. There had been no written contract, but this was not an unusual practice for an 'actress' or minor performer. ${ }^{6}$ By the opening night her lines had been cut from three pages to two lines, then, after two weeks, Thomas was dismissed with a fortnight's notice. The reason given was that some of the original members of the company had returned and had to be placed. Hicks claimed in court that 'Miss Thomas, like other 
chorus girls, was subject to a fortnight's notice', and that 'nobody but a madman would engage a chorus girl in any other way'. Thomas sued Frohman and the Gattis on the grounds that she had been hired as an actress not an 'extra', chorus or a show girl. Luminaries - inevitably all male - from West End theatre managements were called for both sides. Hayden Coffin, Robert Courtneidge and Augustus Moore made appearances in court, and the debate was picked up in the newspapers under such headlines as 'What is an Actress?', with opinions from George Alexander, George Edwardes and Beerbohm Tree generating publicity about the case and its participants. ${ }^{7}$ Thomas's two lines were, 'I am a perfect wonder at spotting winners, and I hardly ever lose at bridge', and 'Dear old Hyde Park'. Charles Wyndham in a written deposition said that 'he considered that a lady who had to speak such lines ... must be intelligent'; 'the words', in his view, 'were so foolish that it required a lot of intelligence to give them life' and therefore Thomas must be an actress who could not be dismissed at a fortnight's notice like a 'show girl'. The dramatist Owen Hall supported Wyndham but went further, arguing that he would describe Thomas as 'a small-part principal'; he himself 'considered the term "show girl" offensive, and one that was not used in high-class theatres'. ${ }^{8}$

Wyndham's judgement might appear facetious but the eventual verdict did turn in part upon the 'intelligence' required to 'give character' to a line and therefore 'act'. ${ }^{9}$ Important as this issue of 'taxonomy' was for the profession, facetiousness appeared to be the dominant mode of legal exchange in court as reported by the newspapers. The barristers, as well as established performers, tended to 'play to the gallery', and in the first trial even Justice Darling - who presided over many of these 'theatrical' trials - mindful of his reputation as a wit, frequently provoked 'loud laughter' with such faux-naive questions as whether 'the person who plays "Hamlet" [would be] engaged on the same terms as the person who says "The carriage waits"? 10

Thomas was awarded $£_{50}$ damages after the second trial, but fought on. Finally, after three trials, the case was found for Thomas, who received $£ 200$ in damages - the equivalent of a good year's salary for her - with costs. ${ }^{11}$ While it is impossible to say what motivated Thomas, she must have had the self-belief and financial means to persevere, though it is possible she also received support from the Actors' Association, whose secretary, Charles Cruickshank, spoke for her at all three trials. Above all, it was sufficiently important to 'Ethel Karri', both financially and personally, for her to fight for her right to be designated an actress, 
rather than a chorus or show girl, with all the connotations that these involved. She risked her future employment prospects by alienating possible employers by being so 'uppity' (as Grahame v. Robertson below shows), but equally she risked lower status and future levels of pay if she did not defend her professional standing.

\section{Defending the body: Studholme v. Foley (1904); Monckton v. Dunn (1907)}

Risk to professional reputation was at the heart of most theatrical libel trials. Some cases were relatively straightforward. The variety artist and actress Hettie Chattell was awarded by a jury the extraordinary sum of $£ 2,500$ in damages from the Daily Mail when the paper falsely named her as the mother of the Gaiety Girl Rosie Boote. Since Chattell was only 28 at the time, and single, the case for defamation was hard to deny. ${ }^{12}$ Since Chattell had only asked for $£ 1,000$ in damages in the first instance, she appears to have accepted this lower sum after the case went to appeal in December, and the Master of the Rolls agreed that although the libel had been 'of a very grave character', he deemed the jury's award 'excessive and out of all proportion to the injury the lady had suffered'. ${ }^{13}$

However, other libel cases were more complex and the defence not simply one of reputation. A significant factor that emerges from these legal disputes was the problem of the copyright ownership of images in the early twentieth century; this became critical with the increased visibility of women performers through changes in print culture. Developments in paper production had reduced the cost of paper exponentially, but it was the invention of the rotary press that truly revolutionised the print industries. The old steam newspaper presses were 'gradually replaced by rotary presses capable of mass production [and] the railways transformed the process of getting the paper to readers anywhere in the country' (Engel, 1996: 56-7). It was not simply newspapers that accelerated the 'celebrity culture' of the 1900s. The rotary press and advances in the mass reproduction of photographs, using lithography as opposed to intaglio engraving, line drawings and woodcuts, enabled not just photographic newspapers - the first was the Daily [Illustrated] Mirror in January 1904 - and populist theatrical magazines such as Play Pictorial (1902-39), but also the photographic postcard industry which became enormously important in the commodification and mass circulation of performers' images (Gardner, 2004a). The law, however, was struggling to keep up with these advances. While Britain was a signatory 
to the 1886 Berlin Convention, which first recognised copyrights among sovereign nations, and the 1891 International Copyright Treaty, it implemented regulation selectively, largely through case law. In the early part of the twentieth century the law relating to ownership of photographic images (by the subject, the photographer or the photographic company) was still in a state of development. ${ }^{14}$

The women who went to law to protect their reputation when it was 'traduced' through the dissemination of an undesirable image were therefore safer using the laws of libel rather than copyright, although to all intents and purposes it was the ownership of their image that was in dispute. Many cases centred on representations of part or the whole of the performer's body. Given the increasing prominence of 'real' images of women in the period through photographic newspapers, magazines and postcards, the negotiation and control of how, how much and for/to whom the body was exposed became critical for the ordinary as well as the celebrity performer.

The musical comedy star Marie Studholme was renowned for her 'bewitching smile' that graced many a 'fancy stationer's window' ${ }^{15}$ Many of the numerous postcard pictures of her focused on 'her wonderful smile' (Jupp, 1923: 69), and perfect dentition. Like many performers, she had capitalised on her 'assets' by allowing her image to be used in advertising. ${ }^{16}$ In an advertisement for Sozodont dentifrice in the $1890 \mathrm{~s}$ she testified that ' $[t] o$ an actress nowadays a pretty set of teeth is a necessity. In burlesque, especially, a smile is as good as a song. And a smile is enhanced if the teeth are pretty, for pretty teeth are an actress' stock in trade' (Figure 11).

When the West End dentist Edward Foley was looking for a 'suitable head to work upon' for a brochure advertising his cosmetic dental practice, he unsurprisingly bought a picture postcard of Marie Studholme. Her teeth, according to the account in the Morning Bulletin, 'were touched up by artists, and a photograph was taken from it, representing "with good teeth." Then several teeth were blacked out, and another photograph was made to indicate "without good teeth." ${ }^{17}$ Half-a-million booklets using the 'before and after' photographs were printed, but Studholme, on hearing about the publication, sued Foley for libel. The matter was settled out of court, but all the booklets were destroyed and Foley was forced to pay damages with costs. He also had to make a 'sincere apology', printed in newspapers designated by Studholme, in which he admitted that having used her portrait 'in a manner calculated to induce persons to erroneously believe that certain of her front teeth 


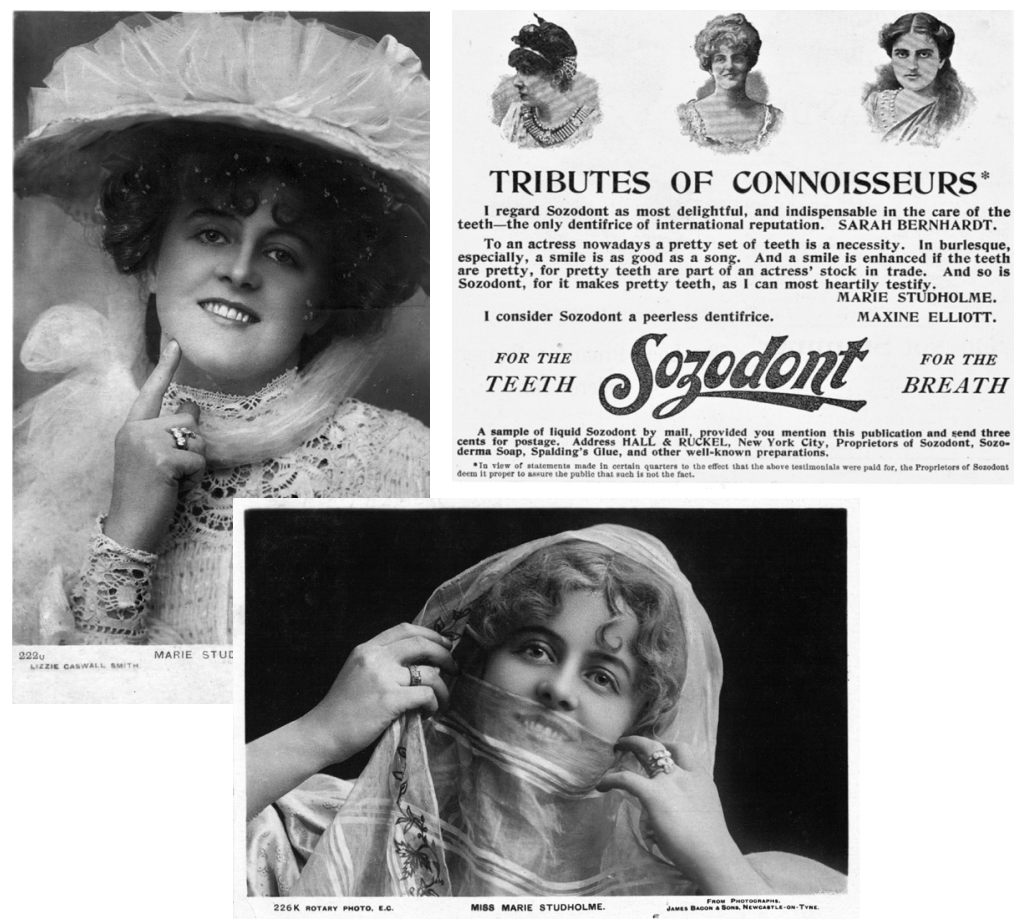

11 Marie Studholme and her bewitching smile.

are missing, and have been replaced with false ones' constituted a libel. 'That particular penny post card involved its purchaser in an outlay of about $£ 200$ ' the Morning Bulletin quipped.

It is doubtful whether the $£ 50$ damages awarded to Studholme, then at the height of her career, was her motive in suing Foley. Like other celebrity women performers from the period, Studholme was very careful of her public image. Despite humble origins in Bradford, she was marketed as the epitome of female beauty in romantic picture hats, fashionable dresses and stage costumes. Though not named at the trial, there were others who had interests in maintaining Studholme's reputation as the perfect romantic beauty. From about 1900 almost all postcards of Studholme were produced by the Rotary Photographic Company from photographs by Frank Foulsham (or the duo Foulsham and Banfield). In the same period she worked almost exclusively for George Edwardes at the Gaiety Theatre. These men's commercial interests were also at stake if 

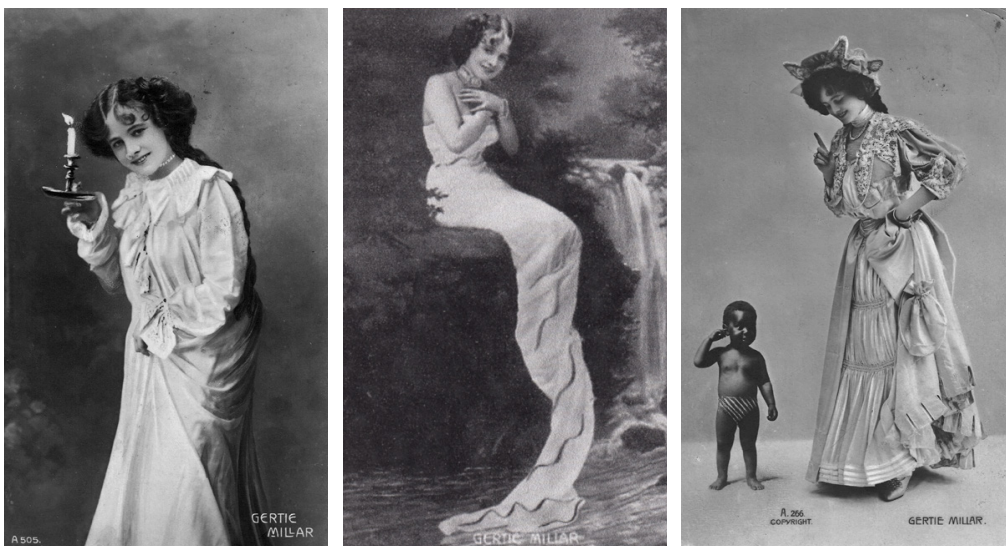

12 Gertie Millar in three pirated postcards by Ralph Dunn (l to r): in a nightdress, as 'La Source', The Orchid.

Studholme's reputation was 'tainted', or if they lost control of the circulation of her image. It is, perhaps, no coincidence that this 'triumvirate' were all represented at a later trial for libel brought by another Gaiety star, Gertie Millar.

In 1907 Millar sued a small postcard publisher, Dunn and Co., for the libel implicit in adding her head to images of other women's bodies on three pirated postcards. The first card showed Millar in a nightgown with a candle in her hand. The second 'was taken from a well-known picture called La Source [in which] the figure was draped in a peculiar way'; counsel for the plaintiff pointed out that 'the attraction of the picture [consisted] in the insufficiency and apparent insecurity of the costume' (Figure 12). The third picture was described as merely 'vulgar and ridiculous' and showed Millar crawling out of an eggshell. ${ }^{18}$

The commercial imperative gradually emerged in the reporting of the case. In court Millar was accompanied by her husband, the composer Lionel Monckton; Foulsham, who was not only photographer for, but also director of, the Rotary Photographic Company; and George Edwardes, who was reported to be 'smiling genially' throughout much of the proceedings. Millar had consulted Foulsham before bringing the action and he introduced her to the solicitor, a fellow director of the Rotary Photographic Company, who went on to represent her in court. ${ }^{19}$ One of the points of dispute in the Millar case was the price at which Ralph Dunn was selling the pirated cards. A Millar card by Rotary, Tuck, 
Philco or Valentine cost 2d, or 3d coloured; Dunn was selling his cards for one penny. Justice Darling, spotting an economic agenda, observed: 'I have been thinking for some time' that this was 'Mr Foulsham's action and not this lady's'; and the defence barrister also expressed the belief that the case had been brought to 'boycott' his client. Replying to these charges, Millar, perhaps disingenuously, pleaded ignorance of any conspiracy by 'the publishers of $2 \mathrm{~d}$ postcards to prevent the publishers of penny cards getting photos from the photographers'. ${ }^{20}$

As in the Studholme case, tellingly, it was not the photographer and/ or the photographic company that sued Dunn under copyright law for the flagrant theft of an image, but the performer making use of the libel laws. In a peculiar twist in the Millar case, it emerged that she, and presumably Rotary, had allowed a pirated image of herself in The Orchid to be published by Dunn a year or so earlier, in which an original photograph of Millar admonishing a spider had been replaced by one with a 'piccanniny' in striped trousers (Figure 12). This fact, however, was not included in the judge's summing-up, as it was a libel not a copyright case. Had a copyright case been brought, presumably this previous lack of action would have undermined the plaintiff's (whether Millar, Foulsham or Rotary) case.

Like Studholme, Millar was at the height of her popularity in 1907, and like Studholme and other stars, her body was repeatedly photographed and commodified, but the image that was projected was highly controlled. She was photographed in role, in pictures that perpetuated images of middle-class domesticity and occasionally in fantastic mockups with her emerging from a cracker for Christmas, or (ironically) an egg at Easter, but always fully and fashionably clothed. She was saucy without being sexual. These photographs were frequently sold as 'real pictures', a fantasy that would have pleased but not fooled her fans. To the modern eye, the pirated pictures are extremely anodyne; in the Edwardian context, however, the sinuously posed 'La Source' image in its 'insufficient' and 'insecure' clothing is suggestive, and while the nightdressed figure is well covered, the tilt of the head lacks only a 'Marie Lloyd' wink to turn it into an invitation. The postcards are of poor quality both pictorially and materially; not the sort of charming, professional image Millar et al. wished to see in circulation. Importantly, they lack the lively, performative quality to be found in a Foulsham or a Bassano photographic card. ${ }^{21}$

The intrinsic performance element in the cards was influential in the final judgment, as was the conduct of the trial. As so often in these 
cases, the papers reported the courtroom scenes as an extension of the plaintiff's onstage performance. The judge, Justice Darling again, became a fellow protagonist, setting up Millar's 'act', and frequently interrupting Dunn's defence to support the actress; the whole affair was repeatedly punctuated by 'loud laughter' from the body of the court. Millar's actual demeanour in court is difficult to determine. The Daily Mirror described her as 'favour[ing] the Court with her most charming smile', sweeping 'gracefully ... into the witness-box', and reported how '[h]er eyes brightened with indignation as counsel called her attention to the pictures'. She is cast as the 'heroine', one who treats the defence counsel's questions 'in the manner with which she addresses stage villains ... with a contemptuous curl of her fair lip'. Counsel on this occasion had need to 'muster up courage' to respond to her before 'getting bolder' and going on to admit that 'it was [his] misfortune never to have seen [her] at the Gaiety'. At which point the feisty heroine transformed into a flirt as a 'roguish smile [came] over Miss Millar's face, "You have missed a treat," she [said]', and counsel gave out 'a sigh over lost opportunities'.22

In what was undoubtedly an attempt to appeal to their female readership, the popular press paid significant attention to Millar's in-court 'costume'. On the first day, the Mirror described Millar as 'being snugly stowed away in a very ample, though perfectly fitting, fur jacket. On her head was the most piquant of fur toques. Her beauty shone demurely through a dainty veil. ${ }^{23}$ The Daily Express records her as 'dressed tastefully in velvet, with white headdress, collar and cuffs' on day two, ${ }^{24}$ which for the Mirror was 'even more entrancing than her first [outfit] ... Her ermine-trimmed toque made every woman in the court envious.' The Mirror justified its interest in Millar's costume, arguing that the 'staidest lawyer could be pardoned for paying close attention to the fair plaintiff's toilet for', it argued tellingly, 'it was on the question of dress that the issue of the case turned'. The Mirror reporter felt that the power of this 'fascinating woman ... looking at her very best' would have swayed the 'ungallant' jury to find in her favour - had she stayed in court for the summing-up. ${ }^{25}$

Whatever her appeal to her public, and the all-male jury, Millar lost the case. It is possible that Millar's 'exceptionality', her stellar 'performance' in court, her perceived theatrical charisma and her clothes-ascostume worked against her interests. The jury found for Dunn, strongly guided by the judge whose summing-up was predicated on the difference between the actress and the 'ordinary woman' and the ownership she therefore had of images of her body. Darling advised the jury that they 
'must act impartially in the matter and must not be affected by the fact that on one side they had got a commonplace man carrying on business and on the other a lady of exceptional charm, exceptional ability and exceptional attractiveness'. He continued:

\begin{abstract}
Mrs Monckton got her living as an actress, and was constantly before the public. She allowed people to photograph her and she took money for it. She also allowed her photograph to appear in fancy costumes. It might well be that if you wished to take a person who lived retired from the world and published a photograph of her in fancy costume, it might be libellous. Supposing, for instance you were to publish a photograph of the vicar's wife as La Source. She would have reason to be annoyed. But that is not quite the same as publishing the picture of a lady, who had often been photographed in fancy costumes, in another fancy costume. ${ }^{26}$
\end{abstract}

The judge's steer to the jury was clear; to a 'reasonable person', there was a difference between an actress and an 'ordinary', private woman, and therefore a difference between their rights to control the ways in which their bodies were disseminated.

\title{
Defending the (professional) self: Grahame v. Robertson (1900); Wood v. Sandow, Sandow Limited \& the Dover Street Studios (1914)
}

Millar was protected from damage to her career by her popularity and the fact that she had her management on her side; if anything the conduct and reporting of the case, as well as the verdict, reinforced her 'exceptionality'. This was not true for the majority of performers; it is rare to come across a case, like Ethel Thomas's, where a non-celebrity performer challenged the powers that controlled their livelihoods through the courts. However, there are examples. In 1898 a provincial actress, Gracie Grahame, was overheard by the manager's wife complaining about backstage conditions in the theatre at Yarrow. Later the manager, $\mathrm{H}$. Robertson, wrote to a fellow manager saying that he would only take up his play 'on the understanding that Mrs. Grahame will not be connected with this show in any shape or form, playing a part or otherwise $\ldots$ as she made herself objectionable to the audience and everyone about the place when she was last here'. Grahame sued Robertson for libel, and while a York jury found in her favour the verdict was successfully challenged on appeal in London. ${ }^{27}$ 

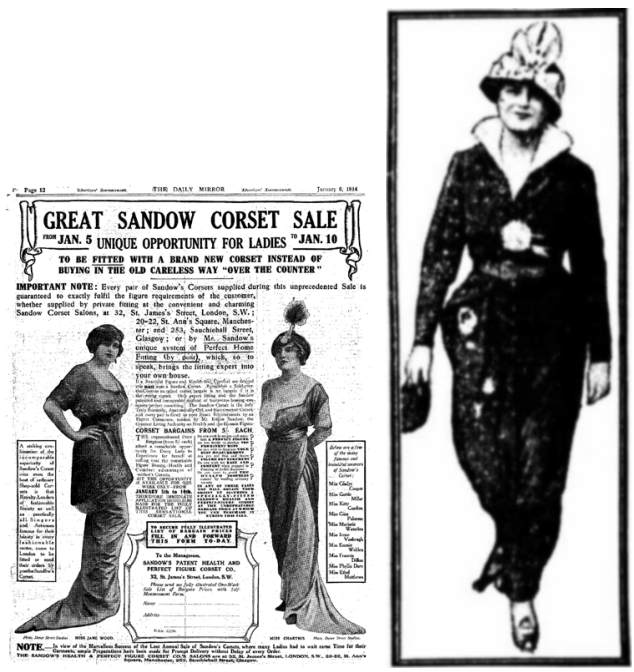

CORSETS IN COURT.

ACTRESS' AMUSING

LIBEL SUIT AGAINST

MR. SANDOW.

JUDGE'S JOKES.

13 Jane Wood in an advertisement for Sandow Corsets, and arriving

at court, 1914.

A more high-profile case was that of Vera Jane Wood, who sued physical culture proselytiser and entrepreneur Eugen Sandow and the Dover Street Studios for libel and infringement of copyright in a photographic image. Wood, a rising young actress, visited the highly reputable Dover Street photographic studios in March 1914. Having relatively recently begun on the stage and achieved some success, she wanted photographs taken and offered to the fashionable papers such as Tatler and The Sketch, which regularly published 'classy' images of musical comedy performers. She received four pictures for her own use, which she paid for, but shortly afterwards she saw her picture being used in a half-page advertisement for Sandow Corsets (Figure 13).

In 1910 Sandow had produced a 'revolutionary' 'Patent Health and Perfect Figure Corset' that was endorsed by celebrity female performers as diverse as Sarah Bernhardt and Irene Vanbrugh, and musical comedy stars Phyllis Dare and Gertie Millar. An album of pictures featuring a 'celebrity' model was available to visitors to his corset salon, or by mail order in a private 'exchange' between corsetière and customer. Wood's mother had seen her daughter's photograph in a newspaper, and it had 'annoyed her'. Asked in court, 'Why did it annoy you?' Miss Wood's mother replied, "The cheap publicity! I wrote at once to my daughter." 
The witness added that she regarded the appearance of this photograph as derogatory to her daughter.' Wood sued on the grounds that she had not given permission for the reproduction of her image in an advertisement, intending her photograph to go to a fashion paper not a 'trade journal'; and secondly, that in so doing the defendants had 'defamed' her. Counsel for the plaintiff argued that the 'illustration suggested that the lady's figure was the result of wearing Sandow's corsets; but the lady had never worn those corsets'. Wood felt that the use of her image in this way 'did her a real injury among her friends'. Her employer, comedian George Graves, confirmed this, testifying that 'in his opinion it would do her no harm or good professionally; but in society he thought it would do harm'. Central to her case was her argument that, because she had not been identified in the advertisement as an actress (on a par with the well-known names in 'the book' and other advertisements), she 'had not been represented as a celebrity, but as a corset model. There was a great difference.' Much was made in court of her respectability - she was a married woman 'with good connections'; her mother confirmed that she had another daughter on the stage 'with her husband' and another 'married to a medical man'. ${ }^{28}$

According to the corset historian Valerie Steele, 'courtesans and actresses were the first to wear conspicuously erotic underwear' (Steele, 2001: 115), and contemporary onstage erotica resembling corsetry further elided differences between the actress and the courtesan. Reputation and representation was therefore still a carefully negotiated area for women performers. While Wood was happy to be identified as an actress - especially in the company of reputable and successful women such as Millar and Gladys Cooper - she was not happy to be identified as a corset model. She was also happy to be represented in fashionable gowns, but not 'in connection with stays' - even with clothes over them; the advertisement, by its very nature, invited the reader to 'imagine' the revolutionary corset underneath the dress.

Wood had none of Millar's support in court. Ranged against her were Sandow and one of the largest photographic businesses in London. Compared to the stars who had agreed to advertise Sandow's corsets, Wood was 'a nobody' with no economic or celebrity power. Despite this, the Wood case, like Millar's, was represented as a performance, with Wood very much 'The Actress'. She is reported to have to responded 'proudly' and to 'retort' when questioned. Her costume is described in detail - 'a blue costume with white collar and a black hat trimmed with white leaves'. The judge in the Wood case, Lord Justice Scrutton, was 
less supportive of Wood than Darling was of Millar, but like him invited levity in the court. He made jokes at the expense not only of Wood but her whole profession when he suggested ('to laughter') that, as an actor, George Graves might be qualified to offer an opinion on his profession but not on 'social [i.e. Society] matters'. He titillated the court when the 'book containing pictures of actresses wearing Sandow corsets' was handed to the jury: 'Ought I to have lady assessors here, or can I rely on the [gentlemen of the] jury?' he asked 'archly', continuing, 'It will distract them horribly if you let them see it.' When counsel was proceeding before all the jurymen had a chance to look at the book, the judge stopped him - 'you are shutting the back row out!' and 'a pause followed while the back row's claims [to see the book] were satisfied'. ${ }^{29}$

In his summing-up, Scrutton, like Darling before him, distinguished between the rights of an actress and of an 'ordinary' woman, saying that if the lady sat as an ordinary customer, the negative was her property. But if she was an actress and wanted to do what other actors and actresses wanted - to have a complimentary sitting so that the photograph should be published by the illustrated papers - then the photograph belonged to the photographer. ${ }^{30}$

There was, therefore, no case to answer. The image as contained in the negative was judged to belong to the subject, not the photographer or the studio, unless that person was an actress. However, like the 'ordinary' sitter, Wood had actually paid for her photographs, not asked for a complimentary sitting, though she had left the negative with the photographer to promote her professional self in the 'fashionable' papers. The studio's use of the photographs, though legal under copyright law, abused the sitter/photographer agreement and exemplified the legal vulnerability of the actress as a public as opposed to private person.

\section{Defending the (private) self: Crown v. Frederick Henry Woofries (1906); Dillon v. Charing Cross Kinematograph Theatre and Barnett (1916)}

The Millar and Wood libel cases show how difficult it was to enforce the boundary between the professional/public self and the private individual in the case of the performer. The celebrity industry had grown exponentially with the 'massification' of the print industries. The private lives of theatre stars were marketed though self-promoting publications such as memoirs, magazine interviews and photo opportunities for newspapers, magazines and postcard images. Gossip circulated freely, 


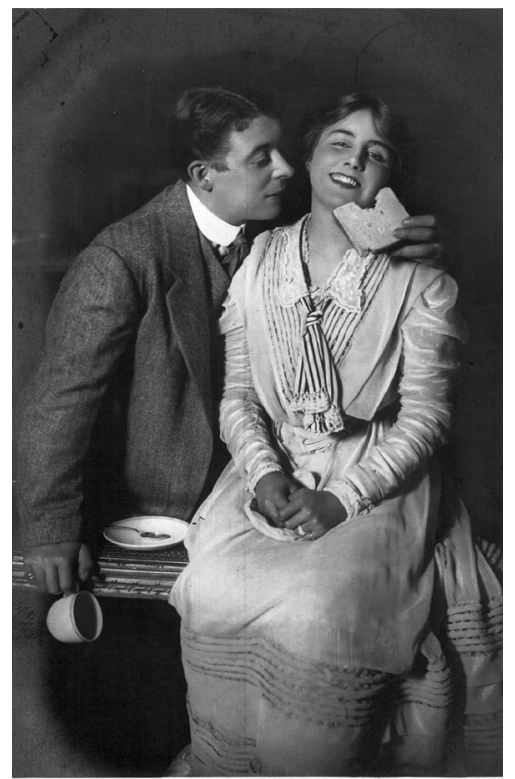

3248 8 "THE OATOH
MR. SEYMOUA HICKS.
as "DuKs Or ST. JenMrNo."

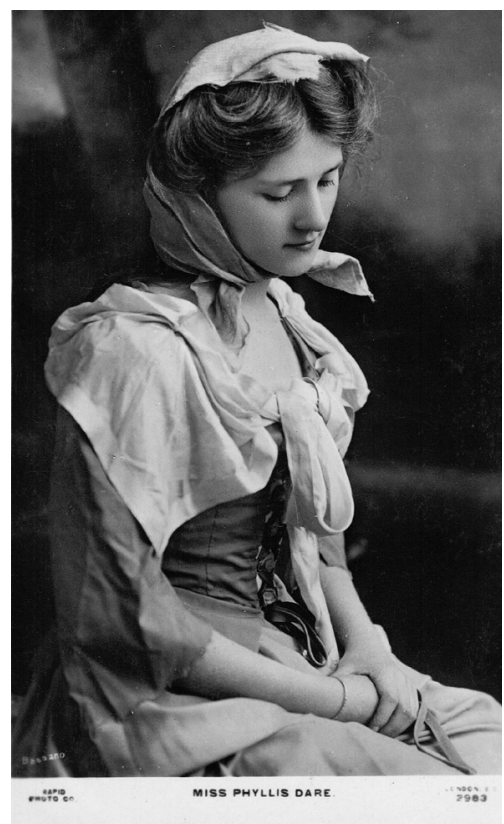

14 Seymour Hicks and 'his nice wife', Ellaline Terris, in The Catch of the Season, 1905; Phyllis Dare in Cinderella, 1905.

constrained only by Britain's imperfect laws of defamation, but rumours often found their way into English-language newspapers overseas. Wellknown figures were particularly at risk for, as the counsel in a libel case involving Phyllis Dare and Seymour Hicks opined in court, 'It might be thought that these atrocious libels would not be believed, but there [are] ignorant people who would believe anything of a libellous nature.' In his view there were people who, 'hearing an appalling story of this kind connected with the theatrical profession', would be more inclined to believe it, expressing 'unctuous horror that such depravity would be possible'. ${ }^{31}$

The 'dastardly accusations circulated by male and female blackguards' (Dare, 1907: 104) about Dare and Hicks were that the 15-yearold Dare, instead of being at a convent school in Brussels completing her education, was 'in trouble in Paris; in fact, expecting to become a mother' (see Maggie B. Gale's chapter in this volume). The culprit was said to be 'no less a person than Mr Seymour Hicks, a man with a nice wife and child', who had drugged 'the poor girl ... by something put in 
some sweets or fruit, and [then] politely told her he does not intend to help her' (Figure 14). ${ }^{32}$ Both Hicks and Phyllis Dare's family had heard the story in London, and Hicks had 'received verbal communications and a considerable number of anonymous letters', causing both families 'the greatest annoyance ... and great unhappiness'. Despite attempts to trace the origins of the scandal, it was not until an employee of Hicks visited a bar in Lime Street, Liverpool, 'much frequented by people connected with the theatrical profession', that the source was found. The story had apparently originated with a young engineer, Frederick Henry Woolfries, who in seeking to hide a criminal past had assumed the name Frederick Vernon Dare and passed himself off as Zena and Phyllis Dare's brother. He spoke 'from time to time of writing to them, gave his landlady their photographs, and left letters addressed to them about his room, so as to give colour to his claim'. ${ }^{33}$ Critically he had written about his 'sister's' plight in four cliché-ridden letters to his 'fiancée', a barmaid at the hotel, in which he talked of being 'absolutely heartbroken' and how 'horsewhipping' was too good for Hicks. ${ }^{34} \mathrm{He}$ had created 'a fairy story' in a 'silly attempt at self-glorification, also an endeavour to obtain fictitious importance in the eyes of the girl he loved'. ${ }^{35}$ Woolfries pleaded guilty to the charge of unlawfully and maliciously publishing defamatory libels of Hicks and Dare and was sentenced to eight months' hard labour.

In his summing-up, the judge warned of the dangers of 'untrue statements ... made in such a place' as Liverpool, 'an important theatrical centre', proliferating and travelling 'quickly through the country'. ${ }^{36}$ The theatre network was itself seen as a contaminant and propagator of scandal. Dare, writing obliquely about her experience in her memoir the following year, fulminated about the stage being the 'happy hunting ground for busybodies and malicious, meddling gossipers, who aspire to "bring down" some luckless member of the profession about whom they think the story they propose to fabricate will be swallowed with avidity by the many to whom they relate the outcome of their imaginative brains'. She finds solace in the 'sweet sympathy [of] thousands of strangers' who realised that rumour had 'probably never before so wronged an actress in the whole history of the stage' (Dare, 1907: 95-9). Dare's response may be hyperbolic, but the attack had been personal.

Even more experienced artists were sensitive to real or imagined attacks on their reputation. In 1916 Marie Lloyd, under her married name of Dillon, sued the Charing Cross Kinematograph Theatre, alleging that she had been 'greatly injured in her reputation and credit, and had been held up to public ignominy' when, in August 1915, they had 
'caused to be exhibited to passers-by in the Strand, in front of their premises, a large poster, containing a portrait, almost life-size' of herself, 'with the words in large letters at the top and bottom of the poster: White Slave Traffic' ${ }^{37}$ The exhibitors knew what they were doing in the juxtaposition of Lloyd's image with the title of the film they were showing alongside footage of Lloyd in performance. In 1913 she and her lover, Bernard Dillon, on arriving in New York, had been detained on Ellis Island and threatened with deportation for 'gross moral turpitude'. They had travelled to America on the liner Olympic as man and wife. Dillon was charged under the 1910 White Slave Act of attempting to take into the country a woman not his wife. Lloyd was charged with being a passive agent. Although the pair were eventually allowed to enter the country on a surety each of $\$ 300$ and on condition they did not live together while in America, Lloyd's sister, Alice, claimed that 'the indignity ... went to Marie's heart in a way she never survived. She could not bear to talk of that awful twenty-four hours' (Gillies, 2001: 237-40).

Lloyd was very clear that the detention was an infringement of her privacy; she told the New York Sun that 'I have always supposed and considered that my private life was my own affair ... [this is] a personal matter, my own business - or', she goes on emphatically, 'it would be if I did not happen to be an actress ... when a drunken woman gets hauled into court she calls herself an actress, and you see the headlines to that effect in the newspapers in the morning. ${ }^{38}$ The Kinematograph Theatre admitted the libel and apologised, but Lloyd was not content to settle until the apology was repeated in court; a public offence required a public apology. ${ }^{39}$

\section{Defending the body, defending the self: Crown v. Billing (1918)}

The public vilification of Maud Allan was accompanied by 'deafening cheers and shouts [and] a storm of applause accompanied by the stamping of feet'. The pandemonium continued 'both in the court, in the hall of the Old Bailey and from a large crowd which had gathered outside'. In the scenes that followed Maud Allan was twice reported to have broken down and wept. A jubilant Billing was photographed 'waving his hat to the cheering crowd'. ${ }^{40}$

The prosecution 'submitted that it was not an accident that Miss Allan had been libelled', ${ }^{41}$ and Billing himself admitted that 'it grieved [him] very much to cross-examine Miss Maud Allan at all' (Hoare, 
1997: 170). He had provoked the prosecution to expose the corruption he saw at the heart of government and society; the 'victim' was almost incidental, but the Maud Allan case exemplifies many of the problems that women had faced in the earlier trials discussed in this chapter. She and Grein had originally brought the case of malicious libel to defend their professional and personal reputations. They had sought to separate the actor from the role. But during the trial, Allan was repeatedly questioned about aspects of her professional and personal life by Billing, who conducted his own defence, much of it irrelevant to the case. Her history as a performer was 'on trial'. Billing set out to prove that it wasn't just that she was a dancer/actress - after all he himself had spent four years on the professional stage - but that she was, through her performances, 'ministering to moral perverts'. ${ }^{42}$ Allan's body was central to the defence's case (Figure 15). She was questioned closely about her costume as Salome, not only in the production, but also in her signature performance of the 'Dance of the Seven Veils'. "Am I right in saying," asked Mr. Billing, "that at the Palace Theatre your dress was mainly composed of beads?" Miss Allan: "No, I had more dress than just beads." Allan went on to describe the costume in detail, ${ }^{43}$ and the critic for the Morning News testified that, in his view, her costume in Salome was 'very light, but not so light as I have seen worn by people of high position lately'. In his summing-up the judge asked the jury to say
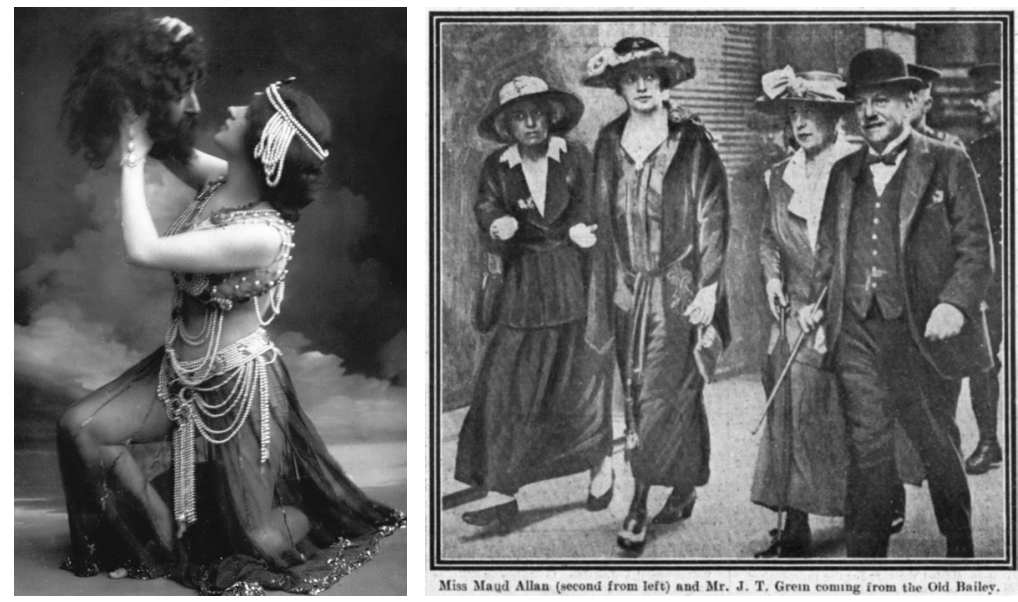

15 Maud Allan as Salome in the 'Dance of the Seven Veils', and outside the Old Bailey, 1918. 
whether 'Miss Maud Allan [was] a sadist, a lewd woman .... because she wore too indecent a costume, too light for the stage'. The jury's verdict said that she was (Kettle, 1977: 265).

Much of Billing's cross-examination of Allan turned upon the conflation of the performer, her self, with the role of Salome. Billing argued that if Salome was, as he believed, 'a grossly immoral play, and one which persons of a healthy mind and wishing to remain healthy would do well not to witness', then 'moral perverts, with their perversions lying dormant, might be led by seeing pantomimic acts of sadism [referring to Salome's sexual excitement as she bites the lips of the dead Jokanaan] to practice them themselves, and that in enacting this, Allan was "committing an act of sadism" herself. Allan responded that she had not written the play. 'But', Billing went on, 'you are acting the play?' To which Allan retorted, in an echo of Charles Wyndham in 1905, 'Does that make me the part because I act it? Of course not ... I was not the play' (Kettle, 1977: 8o-1). But, again, the final judgment said otherwise.

The Allan case may have been pivotal in 'drawing up the battle lines for twentieth century womanhood', but it was also the culmination of two decades in which women performers had begun the fight to control their public and private selves from abuses peculiar to their profession and sex. At the end of the Allan trial Lord Justice Darling observed that '[i]n a very short time women will be able to have their influence upon legislation'. It was another two years before Vida Levering's call for women, like men, to be tried by their peers was achieved. It is unlikely, however, that Darling's concern that women should use their new powers 'to see that much more purity is introduced in public representations than ... at present ${ }^{\prime 4}$ would be shared by many actresses. As the cases discussed here have demonstrated, they had been fighting in the courts for a different type of public representation, for reputation and respect, and a profession where public performance and display did not make them entirely 'public property'. Given Maud Allan's defeat, in 1918 the battle had hardly begun.

\section{Notes}

1 This chapter refers to UK law, most particularly English law; although UK law usually encompasses Ireland and Wales, Scottish law developed slightly differently in some areas. All the cases under consideration took place in England.

2 Votes for Women opened at the Royal Court in 1907; it was published as a 
novel, The Convert, the same year and the play script was published by Mills and Boon in 1909.

3 The civil libel case was originally brought by Allan and Grein against Billing, but it became a criminal, hence Crown, case as an obscene and defamatory libel, an offence against public decency. A full analysis of the trial is beyond the scope of this chapter; however, for that, Grein's role, and more on the other public woman defamed by default in the case, Margot Asquith, see Bland (2013), Hoare (1997), Kettle (1977), Medd (2002).

4 As opposed to statutory or regulatory law - which is also used extensively, but not predominantly, in the UK - or the civil law systems that dominate in Europe, whereby 'past judgments are no more than loose guides'. http://www.economist.com/blogs/economist-explains/2013/o7/economistexplains-10 (accessed 14 January 2016).

5 There is not space here to explore the complex and nuanced relationship between the personal and the professional for the actress, but a reading of the many memoirs and autobiographies from the period show how powerful the hierarchies were within the profession and how this impacted on performers' aspirations. See Davis (1991), Gardner (2004b), Richards (1993), Sanderson (1984).

6 The Era, 23 June 1906, p. 12.

7 Daily Mail, 3 February 1906, p. 5.

8 The Era, 23 June 1906, p. 12.

9 Ibid.

10 Ibid.

11 Thomas had been employed at $£ 3$ a week for the run of The Catch of the Season, and claimed a loss of the $£ 150$ which she would have earned for the whole run, minus the $£_{32}$ she had earned from playing pantomime after her dismissal by Hicks. Thus $£ 200$ was a generous settlement. The Era, 23 June 1906 , p. 12. Average annual nominal earnings in 1905 were $£ 69.67$ ( $£ 25,000$ at 2015 values).

12 St James's Gazette, 13 December 1901, p. 14.

13 The Era, 14 December 1901, p. 23.

14 The history of copyright law is extremely complicated, but the 1911 Copyright Act which implemented the 1886 Berne Convention in part (it did not fully ratify the Berne Convention until 1988) effectively extended the notion of 'author' to all types of work, not just printed material. However, the issue of ownership of a work created in the course of employment, e.g. a photograph, remained problematic until the 1980 .

15 Evening Express, 20 January 1904, p. 2.

16 See Loeb (1994) and Rappaport (2000) for both specific reference to the use of actresses in advertising, and a more general overview of gender and consumer developments in the period. See also Hindson (2011) for an exemplary case study. 
17 Morning Bulletin, 7 March 1904, p. 6. Subsequent quotations in this paragraph are from this source.

18 The Times, 29 January 1907, p. 15.

19 Ibid.

20 See The Times, 30 January 1907, p. 3; Manchester Guardian, 30 January 1907, p. 4.

21 The fashionable photographer Alexander Bassano also worked for Rotary. He opened a studio in 1850 in Regent Street, London, moving to Old Bond Street in 1876. Bassano retired in around 1903, but the premises were refurbished and relaunched as Bassano Ltd, Royal Photographers. http:// www.npg.org.uk/collections/search/person/mpo8062/bassano-ltd (accessed 8 November 2016).

22 Daily Mirror, 30 January 1907, p. 4.

23 Daily Mirror, 29 January 1907, p. 4.

24 Daily Express, 30 January 1907, p. 5.

25 Daily Mirror, 30 January 1907, p. 4.

26 The Times, 30 January 1907, p. 3.

27 The Times, 26 April 1900, p. 3; The Era, 28 April 1900, p. 8.

28 The Times, 27 June 1914, p. 4.

29 Daily Mirror, 27 June 1914, p. 4.

30 The Times, 30 June 1914, p. 4.

31 Daily Mail, 24 September 1906, p. 5.

32 The Times, 25 September 1906, p. 9.

33 Auckland Star, 10 November 1906, p. 13.

34 The Times, 25 September 1906, p. 9.

35 Citizen, 28 November 1906, p. 5.

36 Daily Mail, 28 November 1906, p. 5.

37 Stage Year Book, 1916, p. 194.

38 New York Sun, 4 October 1913, p. 3.

39 The Times, 15 April 1915, p. 3.

40 Daily Mirror, 5 June 1918, p. 3.

41 Ibid.

42 Daily Mail, 31 May 1918, p. 3.

43 Daily Mirror, 5 June 1918, p. 2.

44 Daily Mirror, 5 June 1918, p. 2.

\section{References}

Bland, Lucy (2013), Modern Women on Trial: Sexual Transgression in the Age of the Flapper, Manchester: Manchester University Press.

Dare, Phyllis (1907), From School to Stage, London: Collier.

Davis, Tracy C. (1991), Actresses as Working Women, London: Routledge. 
Engel, Matthew (1996), Tickle the Public: One Hundred Years of the Popular Press, London: Victor Gollancz.

Gardner, Viv (2004a), 'Gertie Millar and the "Rules for Actresses and Vicars' Wives"', in Martin Banham and Jane Milling, eds, Extraordinary Actors, Exeter: Exeter University Press, pp. 97-119.

Gardner, Viv (2004b), 'The Three Nobodies: Autobiographical Strategies in the Work of Alma Ellerslie, Kitty Marion and Ina Rozant', in Maggie B. Gale and Viv Gardner, eds, Auto/biography and Identity: Women, Theatre and Performance, Manchester: Manchester University Press, pp. 10-38.

Gillan, Don, www.stagebeauty.net.

Gillies, Midge (2001), Marie Lloyd: The One and Only, London: Orion Books.

Hindson, Catherine (2011), "Mrs Langtry seems to be on the way to a fortune": The Jersey Lily and Models of Nineteenth-century Fame', in Su Holmes and Diane Negra, eds, The Limelight and Under the Microsope: Forms and Functions of Female Celebrity, London: Continuum, pp. 17-36.

Hoare, Philip (1997), Oscar Wilde's Last Stand, New York: Arcade Publishing.

Jupp, James (1923), The Gaiety Stage Door, London: Jonathan Cape.

Kettle, Michael (1977), Salome's Last Veil: The Libel Case of the Century, London: Granada.

Loeb, Lori Anne (1994), Consuming Angels: Advertising and Victorian Women, Oxford: Oxford University Press.

Medd, Jodie (2002), “"The Cult of the Clitoris”: Anatomy of a National Scandal', Modernism/modernity, 9.1, pp. 21-49.

Nead, Lynda (2002), 'Visual Cultures of the Courtroom: Reflections on History, Law and the Image', Visual Culture in Britain, 3.2, pp. 119-41.

Rappaport, Erika (200o), Shopping for Pleasure: Women in the Making of London's West End, Princeton, NJ: Princeton University Press.

Richards, Sandra (1993), The Rise of the English Actress, Basingstoke: Macmillan.

Robins, Elizabeth ([1909]), Votes for Women, London: Mills and Boon.

Sanderson, Michael (1984), From Irving to Olivier: A Social History of the Acting Profession in England, 1890-1980, London: St Martin's Press.

The Stage Year Book (1916), London: Carson and Cornerford.

Steele, Valerie (2001), The Corset: A Cultural History, New Haven, CT: Yale University Press.

Stretton, Tim (2005), Women Waging Law in Elizabethan England, Cambridge: Cambridge University Press.

Veeder, Van Vechten (1903), 'The History and Theory of the Law of Defamation. I', Columbia Law Review, 3.8, pp. 546-73, http://www.jstor.org/stable/1109121 (accessed 8 April 2016). 